\title{
QUALITY CHARACTERISTICS AND ANTIOXIDANT ACTIVITY OF STIRRED YOGHURT FORTIFIED WITH DESERT TRUFFLE \\ Hamad, E. M. ${ }^{1}$; M.F. Hassan ${ }^{2}$ and I.S. Ashoush ${ }^{3}$ \\ ${ }_{1}^{1}$ Dairy Sci. Dept., Faculty of Agriculture, Cairo University, Giza, Egypt. \\ ${ }^{2}$ Dairy Sci. Dept., Faculty of Agriculture, Sohag University, Sohag, Egypt. \\ ${ }^{3}$ Department of Food Sci., Faculty of Agriculture, Ain Shams University, Cairo, Egypt.
}

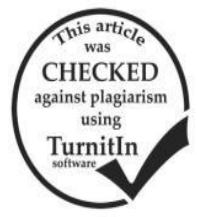

\section{ABSTRACT}

Different kinds of natural food ingredients could be in making yoghurt to produce palatable and more healthy fermented milk. Desert truffle is a popular nutritious food that showed a work was to produce healthy yoghurt supplemented with dessert truffle powder (DTP). Stirred yoghurt was prepared from cow's milk standardized to 3\% fat and supplemented with dried DTP at levels of 1, 3 and 5\% prior to inoculation with yoghurt culture. Resultant stirred yoghurt was analyzed when fresh and after 3,6, and 9 days of the cold storage. Chemical composition of yoghurt milk showed an increased protein and total solids contents. Stirred yoghurt with DTP showed a reduction in both apparent viscosity as well as syneresis during storage period. Sensory evaluation revealed that 1\% DTP is the most acceptable stirred yoghurt compared to 3 and 5\% DTP treatments. There was a correlation between content of phenolic compounds in stirred yoghurt and both quantity of DTP and antioxidant activity. In sum, a healthy stirred yoghurt can be produced by addition of DTP which increased content of phenolic compounds and antioxidant activity of the stirred yoghurt. The highest sensory scores were accounted for $1 \%$ DTP.

Keywords: Stirred yoghurt, Desert Truffle, antioxidant activity, phenolic compounds

\section{INTRODUCTION}

Yoghurt is a popular type of fermented milk. It can be found either as a set or a stirred form, and with or without different flavors. It, generally, is an excellent source of certain water soluble vitamins, i.e. riboflavin, thiamin, folate and niacin, minerals such as magnesium and zinc, and essential amino acids (Tamime, 2002 and Mckinley 2005). Several studies showed the potential health benefits of yoghurt consumption. Individuals suffering from lactose intolerance become a well tolerant towards fermented milk such as yoghurt (Buchowski et al., 2002). It could also be observed that yoghurt can be consumed as a carrier of health promoting microorganisms, which are known as probiotic bacteria (Fooks and Gibson 2002). Chandan and Kilara, (2010) concluded that the production and consumption of yoghurt significantly increased, due to its health benefits and availability of (Chandan and Kilara, 2010).

Several studies were carried out to prepare different types of healthy yoghurt by incorporating certain fruits and natural food ingredients such as fibers and natural antioxidant (polyphenols and flavonoids). Abou El Samh et al. (2013) added black carrot, pumpkin and strawberry to yoghurt in order to improve its antioxidant activity as well as its organoleptic properties. Furthermore, healthy full fat and fat free flavored stirred yoghurt being supplemented with pomegranate juice were of higher antioxidant activity, more acceptable and functional properties, as well as improved sensory properties(Khalil, 2013). Fortification of yoghurt, on the other hand, with grape seed extracts resulted in a product of higher content of polyphenols, and improved antiradical and antioxidant activity of the resultant yoghurt (Chouchouli, 2013).

Mushrooms are considered highly nutritive foods due to their low content of calories, fats, and high content of proteins and of vitamins as well as their pharmacological characteristics (Akyüz et al., 2012). Desert truffle known as EI-Fag'a or EI-Kamah is an edible hypogeous fungi being grown naturally after rainy season in the Saudi Arabia, North Africa (Egypt, Tunisia, Algeria, Morocco) and other parts of the world (Bokhary et al., 1987). Locally, it has an acceptable flavor and of highly nutritive seasonal food. Akyüz M. (2013) found that desert truffle (DT) is rich in linoleic, oleic and palmitic acids, and rich in flavonoids that make it showing a high free radical scavenging activity. In a different study, there was a correlation between antioxidant and antiradical activities of dried desert truffles from four different Middle Eastern countries and phenolic contents (Al-Laith, 2010). Therefore, DT can be used as a source of phenolic compounds that could improve antioxidant activity when added to other food products.

Up to our knowledge, in the literature, there is no published work on the effect of desert truffle on quality and antioxidant activity of yoghurt. Therefore, the objective of the present study was to explore the impact of desert truffle on chemical composition, functional properties, sensory evaluation and antioxidant activity of stirred yoghurt.

\section{MATERIALS AND METHODS}

Milk was purchased from El Marai Company, Qaassim, Saudi Arabia. Yoghurt DVS culture (YC-X11) were obtained from Chr.Hansens, Denmark.

Desert truffle (Terfezia claveryi) fruiting bodies were collected from Buraidah; Qassim, Saudi Arabia during January and February 2016, washed, sliced and dried at $65{ }^{\circ} \mathrm{C}$ in an air-circulated oven until constant weight. Dried slices were subjected to milling to powder and stored at room temperature in the dark until processing and analysis.

Stirred yoghurt was prepared from standardized cow's milk (3\% fat). Sugar (5\%) and skim milk powder (2\%) was added to yoghurt milk. The yoghurt milk was divided into four portions. The first portion was used as control. Desert truffle powder (DTP) was added at the levels of 1,3 and $5 \%$ to the other three portions, respectively. It was found in a small pilot study that DTP have sediments that will affect the sensory 
evaluation of the final product. Therefore, DTP was added on yoghurt milk at $50{ }^{\circ} \mathrm{C}$ with adequate mixing using a stainless steel mixer for 2 min and it was kept on this temperature for another $5 \mathrm{~min}$ to extract soluble compounds from DTP. After that, each yoghurt milk portion were filtered through cheesecloth to remove sediments from DTP, then heated to $90{ }^{\circ} \mathrm{C}$ for $10 \mathrm{~min}$, cooled to $42{ }^{\circ} \mathrm{C}$, inoculated with yoghurt DVS culture at a level of $0.05 \%$, incubated at $42{ }^{\circ} \mathrm{C}$ until coagulation, and transferred to the cold store at $5 \pm 1{ }^{\circ} \mathrm{C}$. On the second day, the obtained yoghurt was mixed for $1 \mathrm{~min}$ using a stainless steel mixer to obtain the stirred yoghurt. Three replicates were made. The analysis of stirred yoghurt was carried out when fresh and after 3, 6 , and 9 days after manufacturing.

Fat, protein, lactose and total solids were determined in yoghurt milk according to Ling (1963). The $\mathrm{pH}$ measurements were carried out using a Laboratory pH meter Type (3305) Jenway Co, England.

Desert Truffle powder was extracted by using methanol: water $(60: 40 \mathrm{v} / \mathrm{v})$ at solvent/powder ratio of 4:1 (v/w) as described by Bloor (2001). To extract the bioactive compounds from fortified stirred yoghurt treatments, a $20 \mathrm{~g}$ of sample were mixed with $30 \mathrm{~mL}$ methanol:water $(60: 40 \mathrm{v} / \mathrm{v})$ and set at $4{ }^{\circ} \mathrm{C}$ overnight. The mixture was centrifuged and the supernatant was then passed through filter paper (Whatman No. 1) to collect the filtrate. An aliquot of their extracts were used for the quantification of total phenolic and DPPH radical scavenging activity as follow:

Total phenolic content was measured by the Folin-Ciocalteu assay along with spectrometer as described by Singleton et al., (1999). Aliquots of $0.5 \mathrm{ml}$ of each extracts were added to $0.5 \mathrm{ml}$ of Folin-Ciocalteu reagent, followed by addition of $0.5 \mathrm{ml}$ of an aqueous $20 \%$ solution of sodium carbonate. The mixture was stirred and allowed to stand for $30 \mathrm{~min}$. The absorbance at $765 \mathrm{~nm}$ was measured using a model UV/VIS 1201 spectrophotometer (Shimadzu, Kyoto, Japan). A blank sample consisting of water and reagents was used as a reference. Gallic acid was applied as a standard, and the results were expressed as $\mathrm{mg}$ gallic acid equivalent (GAE).

The ability of the extracts to scavenge DPPH free radicals was determined by the method described by Blois (1958). Aliquots $(100 \mu \mathrm{l})$ of each extracts were mixed with $2.9 \mathrm{ml}$ of $0.1 \mathrm{mM}$ DPPH in methanol. The control samples contained all the reagents except the extract. The absorbance at $517 \mathrm{~nm}$ was measured after $30 \mathrm{~min}$ of incubation at room temperature. Radical scavenging capacity of each extracts was expressed as percent DPPH radical scavenging effect using the following equation:
Scavenging activity \% $=\left[\left(\mathrm{Abs}_{\text {control }}-\mathbf{A b s}_{\text {sample }}\right) / \mathrm{Abs}_{\text {control }}\right] \times 100$ Measurements of apparent viscosity of stirred yoghurt samples were carried out according to DeninDjurdjević and Jovanović (2002) with some modifications. Brookfield Programmable Rheometer (Model RVDV-III Ultra; Brookfield Engineering Laboratories, Stoughtm, MA, USA) was used for viscosity measurements. All samples were tempered for 5 min at $20 \pm 1{ }^{\circ} \mathrm{C}$. The RV spindle number 3 was used for apparent viscosity measurement at $250 \mathrm{rpm}$. Rheocalc software (ver. 2.5, Brookfield Engineering Laboratories, Inc.) was used to collect the values of apparent viscosity.

Syneresis of stirred yoghurt was determined by centrifugation as described by Keogh and O'Kenned (1998) with some modifications. A sample of $25 \pm 0.1 \mathrm{~g}$ was centrifuged $2500 \mathrm{rpm}$ at $6 \pm 2{ }^{\circ} \mathrm{C}$ for $10 \mathrm{~min}$. The clear supernatant was poured off, weighed and recorded as syneresis (\%). Duplicate measures were taken for each sample.

The color of stirred yoghurt samples was measured using a colorimeter (Model Hunter Lab color Flex) as descriped by Francis (1983). The L, a, and b values were recorded, with $\mathrm{L}$ denoting lightness on a 0 100 scale from black to white; a, red $(+)$ or green $(-)$; and b, yellow (+) or blue (-).

The sensory evaluation of the stirred yoghurt samples was judged by 10 experienced panelists from Department of Food Science and Human Nutrition, College of Agric. and Vet. Med., Qassim Univ., Saudi Arabia using a score test. The stirred yoghurt samples were assessed for flavor (45), mouthfeel \& consistency (25), appearance (15), acidity (15), and overall acceptability (100).

Data were analyzed by one-way analysis of variance (ANOVA), followed by assessment of differences by Tukey's post-hoc test. All statistical calculations were performed using SPSS version 16.0. Results were considered statistically significant at $\mathrm{p} \leq 0.05$.

\section{RESULTS AND DISCUSSION}

Chemical composition of yoghurt milk after addition of $2 \%$ skim milk powder and 5\% sugar is shown in Table (1). It can be observed that addition of desert truffle poder (DTP) was accompanied by a significant elevation in the total solids. This elevation was mainly due to protein content which showed a significant elevation among all treatments when compared to control. There was a tendency in the fat content of yoghurt milk to be increased with the increased quantity of DTP $(\mathrm{P}>0.05)$.

Table (1): Chemical composition of yoghurt milk*.

\begin{tabular}{lcccc}
\hline Treatment & Fat & Protein & Carbohydrates & Total Solids \\
\hline C & $3.10 \pm 0.2^{\mathrm{a}}$ & $4.11 \pm 0.20^{\mathrm{c}}$ & $8.58 \pm 0.35^{\mathrm{b}}$ & $16.50 \pm 0.33^{\mathrm{d}}$ \\
$1 \%$-DTP & $3.13 \pm 0.1^{\mathrm{a}}$ & $4.38 \pm 0.12^{\mathrm{b}}$ & $8.89 \pm 0.32^{\mathrm{b}}$ & $17.21 \pm 0.38^{\mathrm{c}}$ \\
$3 \%$-DTP & $3.17 \pm 0.2^{\mathrm{a}}$ & $4.88 \pm 0.21^{\mathrm{a}}$ & $9.44 \pm 0.21^{\mathrm{b}}$ & $18.36 \pm 0.46^{\mathrm{b}}$ \\
$5 \%$-DTP & $3.21 \pm 0.1^{\mathrm{a}}$ & $5.21 \pm 0.40^{\mathrm{a}}$ & $9.99 \pm 0.28^{\mathrm{a}}$ & $19.56 \pm 0.92^{\mathrm{a}}$ \\
\hline
\end{tabular}

${ }^{*} 2 \%$ skim milk powder and $5 \%$ sugar was added to yoghurt milk for all treatments.

Data are expressed as means \pm SD $(n=3)$. Mean values in the same column within each parameter bearing the same superscript do not differ significantly $(\mathrm{P}>\mathbf{0 . 0 5})$. C: control, DTP: desert truffle powder. 
Previously, the chemical composition of desert truffle (Terfezia claveryi) was found to be $19.59 \%$ protein, $2.81 \%$ fat and $4.64 \%$ ash (Bokhary, and Parvez, 1993 \& Ghulam and Al-Ruqaie, 1999). This could explain the observed elevation of protein content in yoghurt milk of all treatments containing DTP.

From the data presented in Table (2), it could be noticed that desert truffles powder (DTP) are a good source of total phenolic and it had a great free radical scavenging activity. Also, there was a significant difference in total phenolic compounds that was accompanied by an elevation in the scavenging activity between all DTP treatments. These results are in agreement with those of Chaturvedi et al. (2015). The level of phenolic content of yoghurt samples was increases proportionally with level of DTP addition. In addition, by their free radical scavenging capacities, all DTP treatments can lead to a high antioxidant activity. These results are also in agreement with those found by (Pereira et al., 2013) who determined antioxidant activity and phenolic compounds in yoghurt supplemented with different fruits. Therefore, desert truffle powder can be considered as a functional food ingredient because of their antioxidant properties.

Table (2): Total phenolic content and antioxidant activity of Desert Truffles powder (DTP) and yoghurt samples supplemented with Desert Truffles powder.

\begin{tabular}{lcc}
\hline Treatment & Total phenolic $(\mathbf{m g ~ G A E} / \mathbf{g})$ & Scavenging activity $(\%)$ \\
\hline DTP & $42.35 \pm 0.06^{\mathrm{a}}$ & $71.14 \pm 0.20^{\mathrm{a}}$ \\
C & ND & $0.65 \pm 0.02^{\mathrm{e}}$ \\
$1 \%$-DTP & $16.89 \pm 0.04^{\mathrm{d}}$ & $23.12 \pm 0.01^{\mathrm{d}}$ \\
$3 \%$-DTP & $28.44 \pm 0.08^{\mathrm{c}}$ & $33.93 \pm 0.08^{\mathrm{c}}$ \\
$5 \%$-DTP & $36.26 \pm 0.13^{\mathrm{b}}$ & $40.01 \pm 0.02^{\mathrm{b}}$ \\
\hline
\end{tabular}

\section{DTP: desert truffle powder, C: control}

Data are expressed as means \pm SD $(n=3)$. Mean values in the same column within each parameter bearing the same superscript do not differ significantly $(P>0.05)$, ND: Not detected.

Figure (1) is showing $\mathrm{pH}$ values of stirred yoghurt samples during storage period at $5 \pm 1{ }^{\circ} \mathrm{C}$. The $\mathrm{pH}$ values of all stirred yoghurt samples significantly decreased $(p<0.01)$ during storage due to production of lactic acid by yoghurt culture. Addition of DTP at level of $3 \& 5 \%$ showed a slightly increase in $\mathrm{pH}$ value of the yoghurt milk (4.71 and 4.74 and 4.64 for $1 \% \mathrm{DTP}$, $5 \%$ DTP and control, respectively). After 9 days of storage at $5 \pm 1{ }^{\circ} \mathrm{C}, \mathrm{pH}$ value showed also the same trend where $1 \& 5 \%$ DTP showed a slight higher $\mathrm{pH}$ than control. This observation could be due to the presence of polysaccharides in the DTP that affected milk to be coagulated on a little bit higher $\mathrm{pH}$ value. Similarly, Cha et al (2004) found that hot water extracts of mushroom were containing polysaccharides. Besides, yoghurt supplemented with pumpkin showed a higher $\mathrm{pH}$ value which could be due to the presence of protein

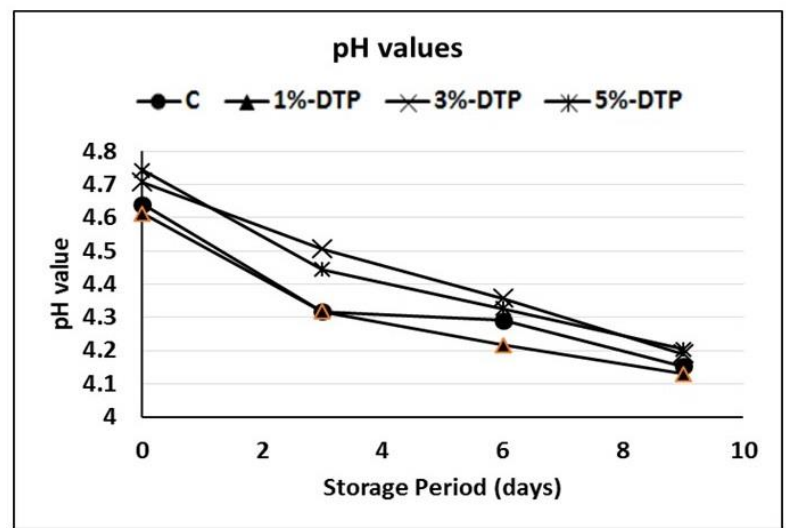

Figure (1): Effect of desert truffle powder (DTP) addition on $\mathrm{pH}$ value of stirred yoghurt during storage period at $5 \pm 1^{\circ} \mathrm{C}$. bound polysaccharides in pumpkin (Caili et al., 2007 \& Abou El Samh et al., 2013).

The values of syneresis of stirred yoghurt are presented in Figure (2). In control sample, the syneresis was showed a slight increase during storage period. As can be observed, the addition of DTP was showed a reduction in syneresis when fresh. The amount of whey separation was decreased with storage in all DTP samples. These results might indicate more water holding capacity of proteins that was higher in the stirred yoghurt when DTP was added. This increased water holding capacity may be lowered release of whey due to reduction of gel matrix rearrangement and electrostatic repulsions between micelles as described by Lee and Lucey, (2010). In agreement with these results, addition of pumpkin to yoghurt was reduced syneresis during storage (Abou El Samh et al., 2013).

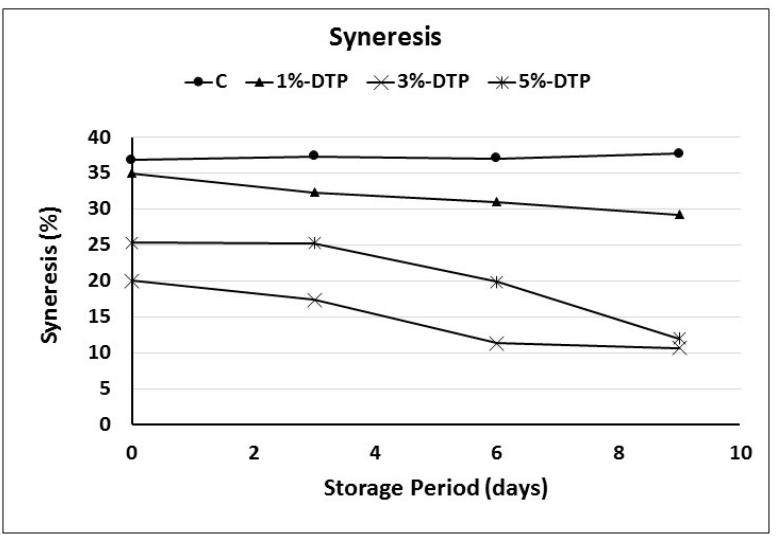

Figure (2): Effect of desert truffle powder (DTP) addition on syneresis of stirred yoghurt during storage period at $5 \pm 1^{\circ} \mathrm{C}$. 
Viscosity of stirred yoghurt samples are shown in Figure (3). Generally, control stirred yoghurt showed the highest values of viscosity among all samples. The viscosity of control was increased in the first 6 days after manufacturing, and then decreased. The results in Figure (3) also revealed that addition of DTP showed a reduction in the values of viscosity of stirred yoghurt. This might indicated that DTP negatively affected the texture of the stirred yoghurt. It is expected that the protein from DTP affected the structure of the gel network of the resulted stirred yoghurt. The number of protein-protein bonds between protein from DTP and casein of milk was small. This might affected the rheological properties due to its effect on casein strands making up the network (Van Vliet, 2000). The present results of viscosity and syneresis are in line with those obtained by (Khalil, 2013) where the stirred yoghurt treatment with $30 \%$ pomegranate juice was showed higher syneresis and lower viscosity values than treatment with $20 \%$ juice.

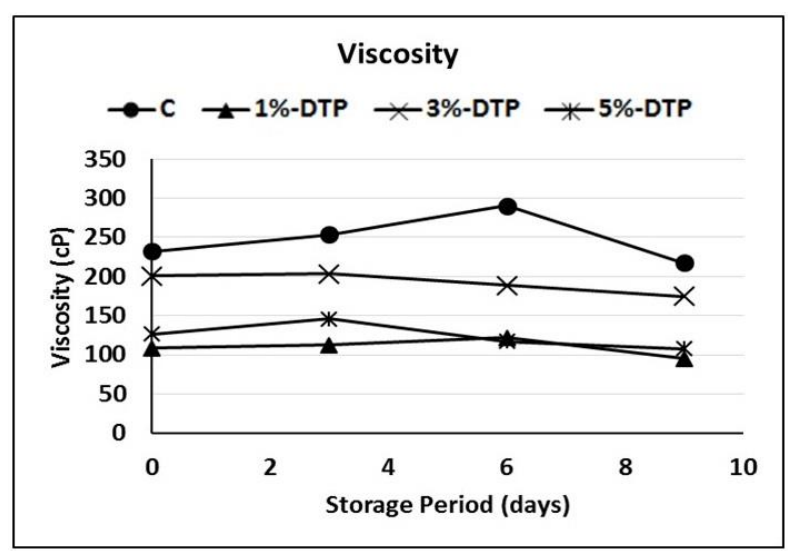

Figure (3): Effect of desert truffle powder (DTP) addition on viscosity of stirred yoghurt during storage period at $5 \pm 1^{\circ} \mathrm{C}$.
Hunter-color values are presented in Table (3). It can be noticed that addition of DTP lowered brightness of the stirred yoghurt. Therefore, the L-value was decreased significantly $(\mathrm{P}<0.05)$ when quantity of the DTP (which have a dark brown color) was increased. Also, a-values was increased in the DTP samples after manufacture and at the end of storage they changed from negative (green) to positive (red) values. Similarly, the b-values were positive and increased with addition of DTP which indicated increase of yellowish color in the samples. During storage, all treatments showed slight changes in the color values. These results showed that addition of DTP changed the color of the stirred yoghurt to a yellowish color that was proportional to the level of DTP in the final product. Previously, other researchers supplemented yoghurt with various fruits and found changes in color values according to the added fruits (Khalil, 2013 \& Chouchouli, 2013).

Sensory evaluation of stirred yoghurt supplemented with DTP is presented in Table (4). As can be noticed, the control stirred yoghurt has gained the highest score of flavor $(44.00 \pm)$, consistency \& mouthfeel (23.83 \pm ), color $(14.17 \pm)$, acidity (14.33 \pm ) and overall acceptability (96.33 \pm ). 1\%-DTP treatment showed a sensory evaluation similar to that of control $(\mathrm{P}>0.05)$ especially scores of flavor (40.83 \pm ) and consistency and mouthfeel (22.00 \pm ) as shown in Table (4). In addition, it can be observed that both 3\%-DTP and 5\%-DTP showed a lower overall acceptability (lowered by $19.7 \% \quad(\mathrm{P}>0.05)$ and $30.1 \% \quad(\mathrm{P}<0.05)$, respectively) when compared with control stirred yoghurt. Some panelists did not accept the 5\%-DTP treatment due to its harsh flavor and its yellowish color. Therefore, the 5\%-DTP showed the lowest scores of flavor, consistency, color, acidity and overall acceptability $(\mathrm{P}<0.05)$. This indicated that panelists prefered stirred yoghurt with the lowest content of DTP $(1 \%)$.

Table 3: Color values of stirred yoghurt samples supplemented with Desert Truffles powder (DTP).

\begin{tabular}{|c|c|c|c|c|}
\hline \multirow{2}{*}{ Treatment } & \multicolumn{4}{|c|}{ Storage Period (days) } \\
\hline & $\mathbf{0}$ & 3 & 6 & 9 \\
\hline & \multicolumn{4}{|c|}{ L-value } \\
\hline $\mathrm{C}$ & $78.82 \pm 0.27^{\mathrm{cd}}$ & $85.49 \pm 0.03^{\mathrm{a}}$ & $87.46 \pm 0.76^{\mathrm{a}}$ & $86.37 \pm 1.30^{\mathrm{a}}$ \\
\hline $1 \%$-DTP & $71.49 \pm 0.34^{\mathrm{de}}$ & $80.36 \pm 0.10^{\mathrm{b}}$ & $77.92 \pm 0.28^{\mathrm{c}}$ & $79.37 \pm 1.01^{\mathrm{bc}}$ \\
\hline 3\%-DTP & $67.70 \pm 0.80^{\mathrm{g}}$ & $73.33 \pm 0.06^{\mathrm{d}}$ & $71.94 \pm 0.75^{\mathrm{de}}$ & $72.21 \pm 1.21^{\mathrm{ed}}$ \\
\hline \multirow[t]{2}{*}{ 5\%-DTP } & $65.68 \pm 0.56^{\mathrm{h}}$ & $70.74 \pm 0.07^{\text {ef }}$ & $69.39 \pm 0.47^{\mathrm{fg}}$ & $70.73 \pm 0.26^{\text {ef }}$ \\
\hline & \multicolumn{4}{|c|}{ a-value } \\
\hline $\mathrm{C}$ & $-2.30 \pm 0.05^{\mathrm{fg}}$ & $-2.41 \pm 0.02^{\mathrm{fg}}$ & $-2.78 \pm 0.26^{\mathrm{g}}$ & $-2.63 \pm 0.11^{\mathrm{fg}}$ \\
\hline 1\%-DTP & $-3.05 \pm 0.03^{\mathrm{g}}$ & $-1.95 \pm 0.04^{\mathrm{fg}}$ & $-2.21 \pm 0.28^{\mathrm{fg}}$ & $-1.90 \pm 0.29^{\mathrm{efg}}$ \\
\hline 3\%-DTP & $-1.26 \pm 0.05^{\mathrm{ef}}$ & $1.54 \pm 0.37^{\mathrm{bc}}$ & $0.47 \pm 0.23^{\text {cd }}$ & $0.21 \pm 1.81^{\mathrm{cd}}$ \\
\hline \multirow[t]{2}{*}{ 5\%-DTP } & $-0.46 \pm 0.05^{\mathrm{de}}$ & $3.07 \pm 0.02^{\mathrm{a}}$ & $1.52 \pm 0.05^{\mathrm{c}}$ & $2.99 \pm 0.14^{\mathrm{ab}}$ \\
\hline & \multicolumn{4}{|c|}{ b-value } \\
\hline $\mathrm{C}$ & $0.74 \pm 0.20^{\mathrm{h}}$ & $9.05 \pm 0.31^{\mathrm{g}}$ & $5.69 \pm 0.21^{\mathrm{ef}}$ & $4.80 \pm 0.51^{\mathrm{f}}$ \\
\hline 1\%-DTP & $7.08 \pm 0.05^{\mathrm{e}}$ & $14.94 \pm 0.18^{\mathrm{c}}$ & $11.93 \pm 0.06^{\mathrm{d}}$ & $13.02 \pm 1.09^{\mathrm{d}}$ \\
\hline 3\%-DTP & $16.44 \pm 0.31^{\mathrm{c}}$ & $20.03 \pm 0.10^{\mathrm{ab}}$ & $18.91 \pm 0.88^{\mathrm{b}}$ & $18.40 \pm 1.41^{\mathrm{b}}$ \\
\hline $5 \%$-DTP & $18.44 \pm 0.05^{\mathrm{b}}$ & $21.23 \pm 0.02^{\mathrm{a}}$ & $21.01 \pm 0.18^{\mathrm{a}}$ & $21.06 \pm 0.29^{\mathrm{a}}$ \\
\hline
\end{tabular}

Data are expressed as means \pm SD $(n=3)$. Mean values in the same column within each parameter bearing the same superscript do not differ significantly $(P>0.05)$. 
Table 4: Sensory evaluation of stirred yoghurt samples supplemented with Desert Truffles powder (DTP).

\begin{tabular}{lccccc}
\hline Treatment & $\begin{array}{c}\text { Flavor } \\
(\mathbf{4 5})\end{array}$ & $\begin{array}{c}\text { Consistency \& } \\
\text { Mouthfeel (25) }\end{array}$ & $\begin{array}{c}\text { Color } \\
(\mathbf{1 5})\end{array}$ & $\begin{array}{c}\text { Acidity } \\
(\mathbf{1 5})\end{array}$ & $\begin{array}{c}\text { Overall } \\
(\mathbf{1 0 0})\end{array}$ \\
\hline C & $44.00 \pm 2.0^{\mathrm{a}}$ & $23.83 \pm 2.0^{\mathrm{a}}$ & $14.17 \pm 1.6^{\mathrm{a}}$ & $14.33 \pm 1.0^{\mathrm{a}}$ & $96.33 \pm 5.1^{\mathrm{a}}$ \\
$1 \%-D T P$ & $40.83 \pm 1.8^{\mathrm{a}}$ & $22.00 \pm 2.3^{\mathrm{a}}$ & $12.50 \pm 1.5^{\mathrm{ab}}$ & $12.83 \pm 1.7^{\mathrm{ab}}$ & $88.17 \pm 6.4^{\mathrm{ab}}$ \\
$3 \%$-DTP & $34.17 \pm 7.4^{\mathrm{ab}}$ & $20.67 \pm 3.7^{\mathrm{a}}$ & $11.17 \pm 3.0^{\mathrm{ab}}$ & $11.33 \pm 2.9^{\mathrm{ab}}$ & $77.33 \pm 14.1^{\mathrm{ab}}$ \\
$5 \%$-DTP & $29.67 \pm 11.2^{\mathrm{b}}$ & $18.50 \pm 5.3^{\mathrm{a}}$ & $9.50 \pm 3.8^{\mathrm{b}}$ & $9.67 \pm 3.4^{\mathrm{b}}$ & $67.33 \pm 21.6^{\mathrm{b}}$
\end{tabular}

Data are expressed as means \pm SD $(n=3)$. Mean values in the same column within each parameter bearing the same superscript do not differ significantly $(P>0.05)$.

\section{CONCLUSION}

The aim of the present study was to produce more healthy fermented milk product by adding desert truffle powder (DTP). The obtained results revealed that DTP increased phenolic compounds content and antioxidant activity of stirred yoghurt. In addition, DTP reduced both syneresis and viscosity values of stirred yoghurt during storage. There was a negative effect on the organoleptic properties of stirred yoghurt when DTP was added. The most acceptable treatment after control was stirred yoghurt with 1\% DTP. Further experiments are required to adjust the desirable percentage of DTP to yoghurt that will gain higher consumer acceptability. More experiments could be done to minimize negative effects of DTP on sensory evaluation, color and viscosity of stirred yoghurt.

\section{REFRENCECS}

Abou El Samh M. M, Abou Dawood S. A., Hebeishy E. H. (2013). Properties and Antioxident Activity of Probiotic Yoghurt Flavored with Black Carrot, Pumpkin and Strawberry. International Journal of Dairy Science, 8(2):48-57.

Akyüz M. (2013). Nutritive value, flavonoid content and radical scavenging activity of the truffle (Terfezia boudieri Chatin). J. Soil Sci. Plant Nutr., 13(1):143-151.

Akyüz, M., Onganer, AN, Erecevit P., Kirbag, S. (2012). Flavonoid contents and 2,2-diphenyl-1picrylhydrazyl radical scavenging activity of some edible mushrooms from Turkey: A. bisporus and Pleurotus spp. Curr. Top. Nutraceut. R. 10, 133-136.

Al-Laith A. A. A. (2010). Antioxidant components and antioxidant/antiradical activities of desert truffle (Tirmania nivea) from various Middle Eastern origins. J. Food Composition and Analysis, 23:15-22.

Blois, M.S. (1958). Antioxidant determinations by the use of a stable free radical. Nature, 181:11991200.

Bloor, S. (2001). Overview of methods for analysis and identification of flavonoids, Methods in Enzymology, 335:3-14.
Bokhary H.A., Suleiman A.A.A., Basalah M.O. and Parvez S. (1987). Chemical Composition of Desert Truffles from Saudi Arabia. Can. Inst. Food Sci. Technol. J., 20 (5):336-341.

Bokhary, H.A. and Parvez, S. (1993). Chemical composition of desert truffles Terfezia claveryi..Journal of Food composition and analysis, 6:285-293.

Buchowski M S, Semenya J and Johnson A O (2002). Dietary calcium intake in lactose maldigesting intolerant and tolerant African-American women. Journal of the American College of Nutrition, 21:47-54.

Caili F. , Haijun T., Tongyi C and Li, Q. (2007). Some properties of an acidic protein-bound polysaccharide from the fruit of pumpkin. Food Chemistry, 100(3):944- 947.

Cha J., Beong-Sam J., Jeong-Won P., Gab-Gyun S., Beom-Kyu K., Hee-Kyu K., Young-Su, C. (2004). Hypoglycemic Effect of Mushroom Fermented Milk in Streptozotocin-Induced Diabetic Rats. Journal of Life Science, 14(4):676-682.

Chandan, R.C. and Kilara A. (2010). Dairy Ingredients for Food Processing. John Wiley and Sons, New York, USA.

Chaturvedi P., Khare K.B., Kwape T. and Makholwa K. (2015). Free radical scavenging and antioxidant properties of a truffle, Kalaharituber pfeilii found in Kalahari deserts of Botswana. International Journal of Bioassays 4(11):4533-4537.

Chouchouli V., Kalogeropoulos N., Konteles S. J., Karvela E., Makris D. P., Karathanos V. T. (2013). Fortification of yoghurts with grape (Vitis vinifera) seed extracts. LWT-Food Science and Technology, 53 (2):522-529.

Denin-Djurdjević J and Jovanović S. (2002). The influence of investigated factors on viscosity of stirred yogurt. J Agric. Sci., 47(2):219-231.

Fooks L J and Gibson G R (2002). Probiotics as modulators of the gut flora. British J Nutr., 88:S39-S49.

Francis F.J. (1983). Colorimetry of foods. In Peleg, M. and E.B. Bagly. Physical Properties of foods. pp 105-123. The AVI publishing company Inc. Westport, Connecticut, USA. 
Ghulam H. and Al-Ruqaie I M. (1999). Occurrence, Chemical Composition, and Nutritional Value of Truffles: An Overview. Pakistan Journal of Biological Sciences, 2(2):510-514.

Keogh M.K. and O'Kenned B.T. (1998). Rheology of Stirred Yogurt as Affected by Added Milk Fat, Protein and Hydrocolloids. J Food Sci.,63(1):108-112.

Khalil R.A.M. (2013). The use of pomegranate juice as a natural source for antioxidant in making functional yoghurt drink. Egyptian J. Dairy Sci., 41: 137-149.

Lee, W. J. and Lucey, J. A. (2010). Formation and Physical Properties of Yogurt. Asian-Aust. J. Anim. Sci., 23(9): 1127 - 1136.

Ling, E. R. (1963). A text book of dairy chemistry. Vol.2,3rd ed. Chapman and hall Ltd. 37. Esser Str., Lonodon, W. C. Z.

Mckinley MC. (2005). The nutrition and health benefits of yoghurt. A review. Inter. J Dairy Tech., 58(1):1 - 12 .
Pereira E., Barros L. and Ferreira C. F. R. I. (2013). Relevance of the Mention of Antioxidant Properties in Yogurt Labels: In Vitro Evaluation and Chromatographic Analysis. Antioxidants, 2:62-76.

Singleton, V.L.; R., Orthofer, and R.M., LamuelaRavento's (1999). Analysis of total phenols and other oxidation substrates and antioxidants by means of Folin-Ciocalteu reagent. Methods in Enzymology, 299:152-178.

Tamime A Y (2002). Fermented milks: a historical food with modern applications- a review. European Journal of Clinical Nutrition 56 S2-S15.

van Vliet, T. (2000). Structure and rheology of gels formed by aggregated protein particles. In: Hydrocolloids. Part 1. (Ed. K. Nishinari). Elsevier Applied Science, Amsterdam. pp. 367377.

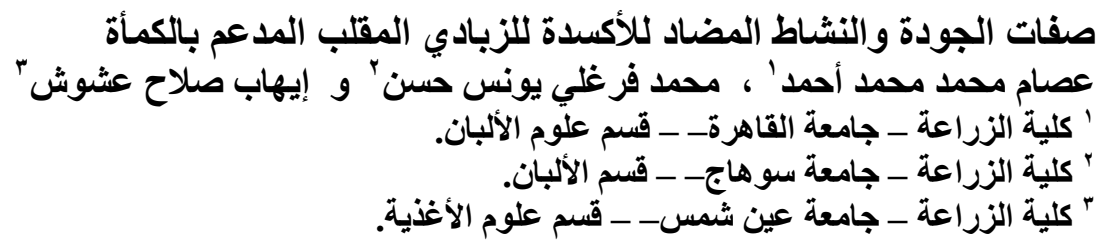

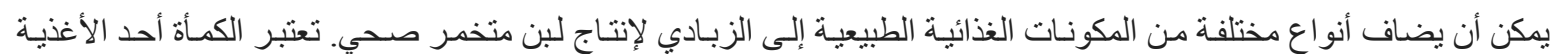

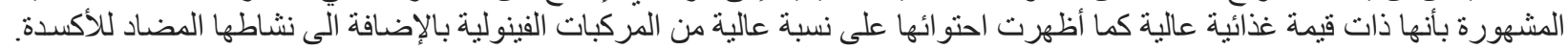

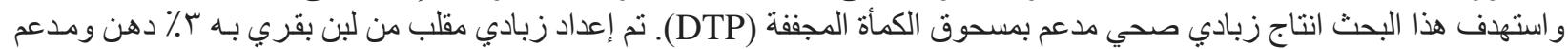

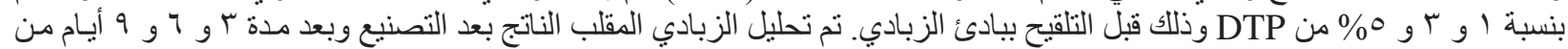

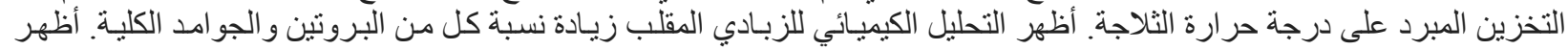

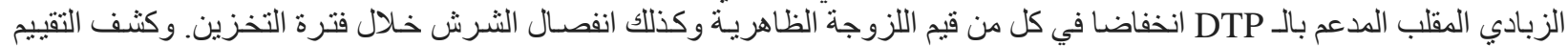

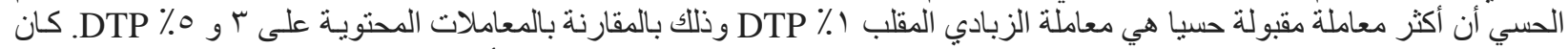

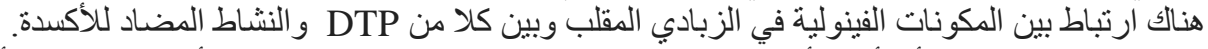

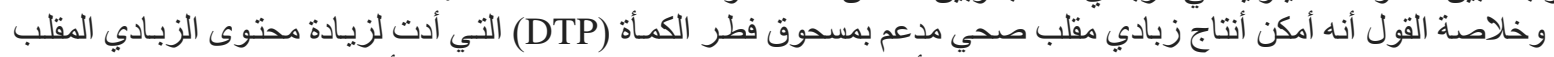

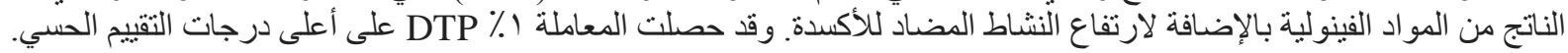

